\title{
ELISA Inhibition Technique for the Demonstration of Sulphones in Body Fluids I. Sulphones Specific Antibody-enzyme Conjugate*
}

\author{
HAN HUIKESHOVEN, MADELEINE de WIT, ANYA SOETERS, \\ TEUNIS A. EGGELTE, J. E. LANDHEER and D. L. LEIKER
}

Royal Tropical Institute, Amsterdam, The Netherlands

\begin{abstract}
A sulphones specific antibody-enzyme conjugate was developed as a basic tool for an enzyme linked immunosorbent assay (ELISA) for dapsone. The conjugate was found to be specific for sulphones without significant cross-reactions with sulphonamides. The sensitivity for dapsone is in the $\mathrm{ng} / \mathrm{ml}$ range. This may lead to a simple and sensitive ELISA inhibition technique for the qualitative demonstration of sulphones in body fluids.
\end{abstract}

\section{Introduction}

From the first therapeutic experiments with dapsone in 1937 techniques were needed to determine or quantify sulphones in biological fluids or pharmaceutical preparations. Methods have been used, ranging from simple colour tests (Buttle et al., 1937; Balakrishnan, 1968) to the sophisticated high performance liquid chromatography (HPLC) techniques (Murray et al., 1971, 1975; Carr et al., 1978; Mannan et al., 1978). Whereas the latter are quite satisfactory for work in advanced laboratories, the former do not fully satisfy the needs of the man in the field. The WHO Expert Committee on Leprosy (1977) asks for "simpler methods for analysing urine for dapsone content" in order to monitor patient compliance with treatment in leprosy.

Our time is witnessing an explosive development of enzyme immunoassays for qualitative and quantitative estimations of all kinds of substances in biological fluids (Wisdom, 1976). These methods often pair high sensitivity

* This investigation received support from the Chemotherapy of Leprosy (THELEP) component of the UNDP/World Bank/WHO Special Programme for Research and Training in Tropical Diseases.

Received for publication 18 May, 1979.

0305-7518/79/040275+07/\$02.00/0

- 1979 British Leprosy Relief Association 
to simplicity, also when applied to the determination of drugs (Brattin and Sunshine, 1973; Mulé et al., 1974). We have therefore engaged in the development of a sulphones specific antibody-enzyme conjugate as a basic tool for an enzyme linked immunosorbent assay (ELISA) for dapsone. Initial studies have shown the feasibility of such an assay (Huikeshoven et al., 1978).

\section{Materials and Methods}

\section{ANTISERUM TO DAPSONE}

Using equimolar amounts of dapsone (DDS) and nitrous acid, monodiazotized DDS was prepared and coupled to horseshoecrab hemocyanin (Williams and Chase, 1976). The resulting hemocyanin-DDS conjugate was purified by gel filtration on a Sephadex G 25 column. The number of DDS residues introduced into a protein molecule (molecular weight 70,000 ) was estimated by colorimetry to be between 15 and 20 (Bratton and Marshall, 1939).

Rabbits received intramuscularly $3 \mathrm{mg}$ of hemocyanin-DDS in $1 \mathrm{ml}$ Freund's Complete Adjuvant. Booster injections with $3 \mathrm{mg}$ of conjugate in Freund's Incomplete Adjuvant were given after 6 weeks and at three-weekly intervals thereafter (for over 1 year now). One week after each booster in jection $25 \mathrm{ml}$ blood was taken by venapuncture to yield about $12 \mathrm{ml}$ antiserum at a time.

\section{ISOLATION OF SULPHONES SPECIFIC ANTIBODY}

The Ig fraction of the antiserum was precipitated with $50 \%$ saturated ammonium sulphate. After washing, dialysis and lyophilization the yield was $25 \mathrm{mg} \mathrm{Ig}$ per ml serum.

Of this product $50 \mathrm{mg}$ was dissolved in $10 \mathrm{ml} 0.01 \mathrm{M}$ phosphate buffered saline of $\mathrm{pH} 7.2$ (PBS) and mixed $\left(16 \mathrm{~h}, 4^{\circ} \mathrm{C}\right)$ with a $50 \mathrm{ml}$ batch of immunosorbent prepared by conjugating horseshoecrab hemocyanin to activated Sepharose 4B. The mixed immunosorbent was filtrated with suction and the filtrate was mixed $\left(4 \mathrm{~h}, 4^{\circ} \mathrm{C}\right)$ with a $50 \mathrm{ml}$ batch of a second immunosorbent prepared by coupling DDS to activated $\mathrm{CH}$-Sepharose 4B (Affinity Chromatography. Principles and Methods, Pharmacia, 1976). Also this mixed immunosorbent was filtrated with suction and then washed with PBS. The washed immunosorbent was mixed with $25 \mathrm{ml} 0.1 \mathrm{~N}$ glycine $\mathrm{HCl}$ buffer of $\mathrm{pH} 2.8$ and immediately filtrated with suction, followed by a wash with $25 \mathrm{ml}$ PBS to neutralize the filtrate as quickly as possible. The filtrate was dialysed $(16 \mathrm{~h}$, $4^{\circ} \mathrm{C}$ ) against distilled water (adjusted to $\mathrm{pH} 7$ by a drop of diluted ammonia solution) and finally lyophilized. The yield was about $2 \mathrm{mg}$ sulphones specific immunoglobulins.

\section{CONJUGATION OF ANTIBODY AND PEROXIDASE}

Horseradish peroxidase $(10 \mathrm{mg})$ was conjugated to sulphones specific Ig (20 mg) according to the method of Nakane and Kawaoi (1974), but without removal of free peroxidase on a Sephadex G 200 column. Instead the enzyme-immunoglobulin conjugate (E-Ig) was precipitated with $50 \%$ 
saturated aqueous ammonium sulphate solution. The product, taken up in $2 \mathrm{ml}$ water, was dialyzed against $\mathrm{PBS}\left(16 \mathrm{~h}, 4^{\circ} \mathrm{C}\right)$ and stored at $+4^{\circ} \mathrm{C}$ in a final volume of $2.5 \mathrm{ml}$.

\section{E-Ig DOSE-RESPONSE CURVE}

A bovine serum albumin DDS conjugate (BSA-DDS) was prepared in the same way as the hemocyanin-DDS described above. Each well of a polystyrene microlitre tray (Cooke F) was incubated with a solution of $0.2 \mu \mathrm{g}$ BSA-DDS in $100 \mu \mathrm{l}$ carbonate buffer of $\mathrm{pH} 9.6\left(15 \mathrm{~min}, 56^{\circ} \mathrm{C}\right)$. The tray was washed 4 times with PBS containing $0.05 \%$ Tween 20 (PBS/Tween), each time leaving the fluid in the wells for $1 \mathrm{~min}$.

The E-Ig dialyzate was diluted fivefold with PBS/Tween containing 5\% normal horse serum (PBS/Tween/Serum). Starting from this dilution 12 twofold serial dilutions in PBS/Tween/Serum were prepared. PBS/Tween $(50 \mu \mathrm{l})$ was added to each well, followed by $50 \mu \mathrm{l}$ of one of the $12 \mathrm{E}-\mathrm{Ig}$ dilutions. The tray was incubated $\left(15 \mathrm{~min}, 56^{\circ} \mathrm{C}\right)$ and washed with PBS/Tween as above.

The enzyme substrate 5-amino-salicylic acid (5AS) was purified according to the method of Ellens and Gielkens (personal communication). $12 \mathrm{~g}$ 5AS was dissolved in $1500 \mathrm{ml}$ water of $80^{\circ} \mathrm{C}$ together with $12 \mathrm{~g}$ sodium bisulphite. After filtration over active carbon and cooling to $4^{\circ} \mathrm{C}$ the precipitate was washed and dried in the air. Portions of $10 \mathrm{mg}$ were dissolved in $10 \mathrm{ml}$ PBS of pH 7.0 containing 0.0001 M EDTA. Each portion was lyophilized, and dissolved in $9 \mathrm{ml}$ distilled water when needed. Immediately before use $1 \mathrm{ml}$ of $0.05 \% \mathrm{H}_{2} \mathrm{O}_{2}$ was added. Each well of the tray was incubated with $100 \mu \mathrm{l}$ of the $5 \mathrm{AS} / \mathrm{H}_{2} \mathrm{O}_{2}$ solution ( $1 \mathrm{~h}$, room temperature). The reaction was stopped by the addition of $25 \mu$ l of $2 \mathrm{~N} \mathrm{NaOH}$.

Relative quantification of this ELISA was done by measurement of the optical density at $449 \mathrm{~nm}$ (O.D. 449) in a spectrophotometer. A dose-response curve was obtained by plotting O.D. 449 as a function of the logarithm of the E-Ig dilution factor.

\section{INHIBITION BY SULPHONES AND ANALOGUES}

From the dose-response curve a point was chosen where relatively maximal slope was paired to relatively maximal O.D. 449. The corresponding E-Ig

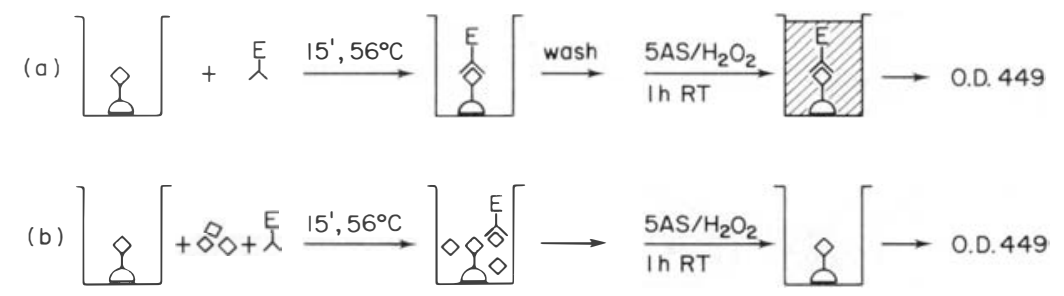

Fig. 1. The ELISA (a) is inhibited by sulphones (b).

Symbols: $\vartheta=\operatorname{DDS}(\diamond)$ conjugated to BSA $(\bullet) ; \quad$ 숫 E-Ig; $\diamond=$ sulphones. 
dilution was used to study the inhibitory action of sulphones and analogues on the ELISA. For this purpose $50 \mu \mathrm{l}$ of serial dilutions in PBS/Tween/Serum of the compounds under test were added to the wells before $50 \mu \mathrm{l}$ of the E-Ig solution was added and incubated $\left(15 \mathrm{~min}, 56^{\circ} \mathrm{C}\right)$. The substrate was added after washing and the product was measured as above.

The principle of the ELISA and the inhibition tests is illustrated in Fig. 1.

\section{Results}

Fig. 2 is a photograph of the ELISA results on which the dose-response curve for the sulphones specific E-Ig conjugate was based. From this curve (Fig. 3) an E-Ig dilution factor of $5 \times 10^{-3}$ was chosen for the inhibition tests with sulphones and analogues.

Fig. 4 is a photograph of the ELISA inhibition tests on which the graphs of Fig. 5 were based. Table 1 gives the sensitivities of E-Ig for the compounds tested, expressed in molarity of the solutions used at $50 \%$ response. The table moreover gives the relative specificities of E-Ig for the compounds, expressed as percentage cross-reaction towards DDS.

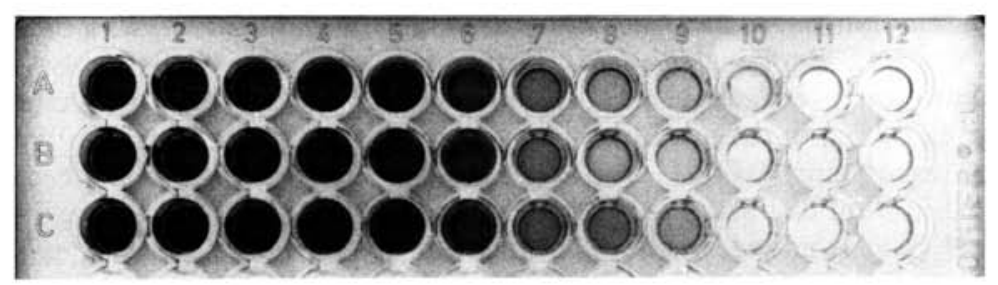

Fig. 2. ELISA of sulphones specific E-Ig. Twof old serial dilutions in triplicate.

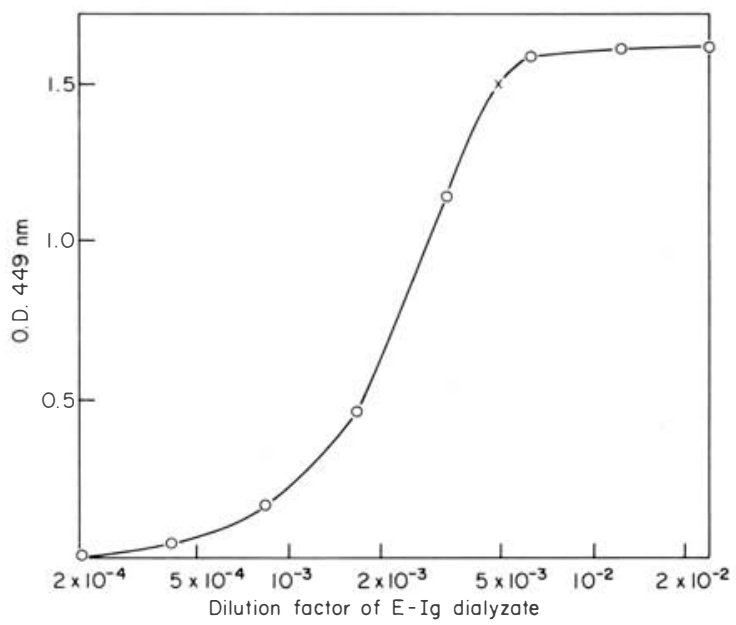

Fig. 3. Dose-response curve for sulphones specific E-Ig in ELISA. From the curve an E-Ig dilution factor of $5 \times 10^{-3}(\times)$ was chosen for the inhibition tests. 


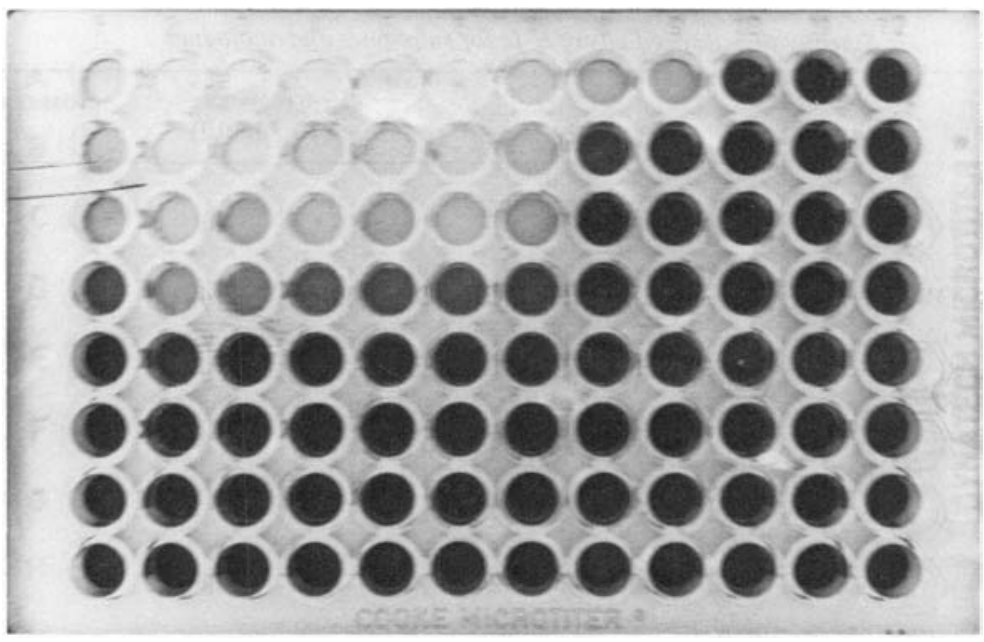

Fig. 4. ELISA inhibition tests of sulphones and analogues. $\mathrm{A}-\mathrm{H}$ are fourfold serial dilutions of the compounds tested. Row numbers correspond to compound numbers in table 1 . Row 12 contains blank controls (E-Ig without additional compound).

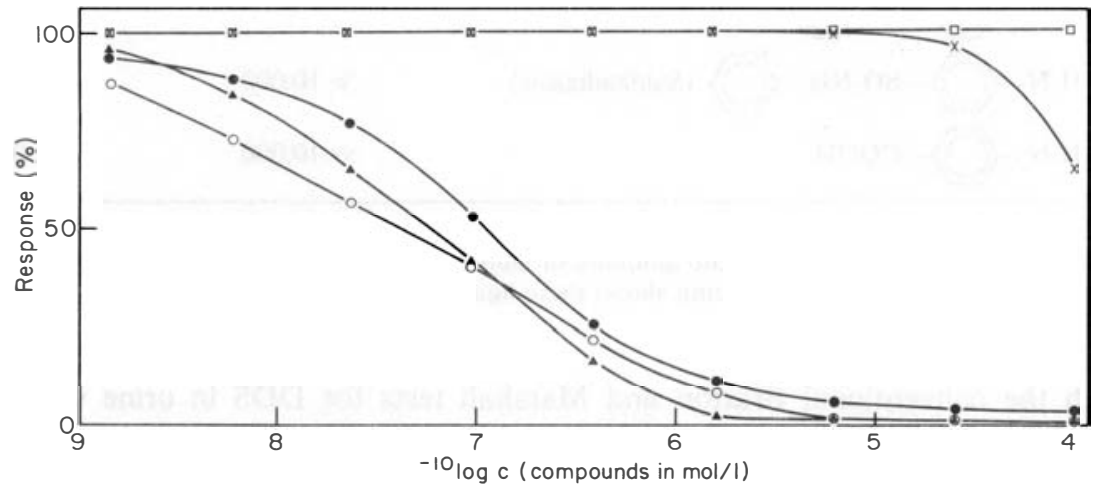

Fig. 5. ELISA inhibition curves for some sulphones and one sulphonamide.

$\bullet$, DDS; O, DADDS; $\Delta$, MADDS; $\times$, Diphenylsulphone; $\square$, Sulphadiazine. (100\% response $=$ no inhibition).

\section{Discussion}

Our final goal is to develop a simple and sensitive ELISA inhibition technique for the demonstration of dapsone in fluids. Pilot experiments with 44 urines of Kenyan leprosy patients have shown the feasibility of such a technique (Huikeshoven et al., 1978). Results of the present study indicate that an ELISA inhibition technique with the E-Ig conjugate might be sensitive to $10^{-7} \mathrm{mmol}$ DDS per ml, which is equal to $25 \mathrm{ng} / \mathrm{ml}$. This compares favourably 
TABLE 1

Sensitivity and specificity of E-Igfor sulphones and analogues

\begin{tabular}{|c|c|c|}
\hline Compound & $\begin{array}{r}50 \% \text { response } \\
\left(10^{-8} \mathrm{~mol} / \mathrm{l}\right)\end{array}$ & $\begin{array}{r}\text { cross reaction } \\
(\%)\end{array}$ \\
\hline 1. $\mathrm{H}_{2} \mathrm{~N}$ & 11 & 100 \\
\hline 2. $\mathrm{CH}$ & DS) & 275 \\
\hline 3. $\mathrm{H}_{2} \mathrm{H}$ & 6 & 183 \\
\hline 4. $\mathrm{H}_{2} \mathrm{~N}$ & 6 & 183 \\
\hline 5. $\mathrm{H}_{2} \mathrm{~N}$ & 7 & 157 \\
\hline 6. $\mathrm{H}_{2}$ & 10 & 110 \\
\hline 7. & 10 & 110 \\
\hline 8. & $>10,000$ & $<0.1$ \\
\hline 9. $\mathrm{H}_{2} \mathrm{~N}$ & $>10,000$ & $<0.1$ \\
\hline 10. $\mathrm{H}_{2} \mathrm{~N}-$ & $\gg 10,000$ & $\ll 0.1$ \\
\hline 11. $\mathrm{H}_{2} \mathrm{~N}-$ & $\gg 10,000$ & $\ll 0.1$ \\
\hline
\end{tabular}

The $100 \%$ response value is the O.D. 449 measured when no sulphone or analogue was added. The first column of figures indicates the amounts of sulphones or analogues needed to reduce the response to $50 \%$. The second column shows these figures relative to the one for DDS $(=100 \%$ cross reaction).

with the conventional Bratton and Marshall tests for DDS in urine with a sensitivity in the $\mu \mathrm{g} / \mathrm{ml}$ order (Ellard et al., 1974). Neither the Bratton and Marshall reagent nor our E-Ig are absolutely specific for DDS. They cross-react with other sulphones. This is no real problem as long as there is no need for a test that distinguishes between DDS and its metabolites or conjugates. Crossreaction with sulphonamides however, one of the real problems of the Bratton and Marshall test, is negligible with the E-Ig conjugate. The conclusion must be that an ELISA inhibition technique for DDS may be a useful development for the man in the field, if workload, cost, and shelf-life of the reagents all prove to be satisfactory. According to Voller and his colleagues (1977) ELISA stands a fair chance in these regards. If however exact information about quantities of DDS, distinguished from its metabolites and conjugates, is wanted, separation methods will be needed with unavoidable loss of simplicity and therefore loss of attractiveness for the fieldworker. Yet in sophisticated laboratories sulphones specific E-Ig might profitably be used in parallel with other sensitive analytical tools. 


\section{References}

Affinity Chromatography. Principles and Methods. (1976). Pharmacia Fine Chemicals. Uppsala, Sweden.

Balakrishnan, S. (1968). Application of a spot test for detection of DDS in urine. Lepr. India 40, 1.

Brattin, W. J. and Sunshine, I. (1973). Immunological assays for drugs in biological samples. Am. J. Med. Techn. 39, 223.

Bratton, A. C. and Marshall, E. K. (1939). A new coupling component for sulfanilamide determination. J. Biol. Chem. 128, 537.

Buttle, G. A. H., Stephenson, D., Smith, S., Dewing, T. and Foster, G. E. (1937). The treatment of streptococcal inf ections in mice with $4: 4^{\prime}$ diaminophenylsulphone. Lancet, i, 1331.

Carr, K., Oates, J. A., Nies, A. S. and Woosley, R. L. (1978). Simultaneous analysis of dapsone and monoacetyldapsone employing high performance liquid chromatography: a rapid method for determination of acetylator phenotype. Br.J.clin. Pharmac. 6, 421.

Ellard, G. A., Gammon, P. T., Helmy, H. S. and Rees, R. J. W. (1974). Urine tests to monitor the self-administration of dapsone by leprosy patients. Am. J. trop. Med. Hyg. 23, 464.

Huikeshoven, H., Landheer, J. E., v. Denderen, A. C., Vlasman, M., Leiker, D. L., Das, P. K., Goldring, O. L., and Pondman, K. W. (1978). Demonstration of dapsone in urine and serum by ELISA inhibition. Lancet, $\mathbf{i}, 280$.

Mannan, C. A., Krol, G. J. and Kho, B. T. (1977). High-speed liquid chromatographic analysis of dapsone and related compounds. J. Pharm. Sci.66, 1618.

Mulé, S. J., Bastos, M. L. and Jukof sky, D. (1974). Evaluation of immunoassay methods for detection, in urine, of drugs subject to abuse. Clin. Chem. 20, 243.

Murray, J. F., Jr., Gordon, G. R. and Peters, J. H. (1971). A chromatographic-fluorometric procedure for the determination of nanogram quantities of antileprotic sulfones $J$. Lab. Clin. Med. 78, 464.

Murray, J. F., Jr., Gordon, G. R., Gulledge, C. C. and Peters, J. H. (1975). Chromatographicfluorometric analysis of antileprotic sulfones. J. Chromatogr. 107, 67.

Nakane, P. K. and Kawaoi, A. (1974). Peroxidase-labeled antibody. A new method of conjugation. J. Histochem. and Cytochem, 22, 1084.

Voller, A., Bidwell, D. E., Bartlett, A. and Edwards, R. (1977). A comparison of isotopic and enzyme immunoassays for tropical parasitic diseases. Trans. R. Soc. trop. Med. Hyg., 71, 431.

Willians, C. A. and Chase, M. W. (1967) Methods in Immunology and Immunochemistry. Volume 1: Preparation of Antigens and Antibodies. New York and London: Academic Press.

Wisdom, B. (1976). Enzyme-immunoassay. Clin. Chem. 22, 1243.

World Health Organization (1977). WHO Expert Committee on Leprosy. Bull. Wld. Hlth. Org. Tech. Rep. Ser., No. 607. 